\title{
不規則に配置された可燃性立方体群の燃え拡がりに対する有限サイズスケーリング \\ Finite size scaling of flame spread along the randomly arranged combustible cubes
}

\author{
○学 吉田 行伸（弘前大院） 正 伊藤 昭彦（弘前大院） 正 鳥飼 宏之（弘前大院） \\ Yukinobu Yoshida, Akihiko Ito and Hiroyuki Torikai \\ Hirosaki University, 3 Bunkyo, Hirosaki 036-8561
}

\begin{abstract}
The objective of this study is to predict the flame spread probability over urban fire by the ratio of non-combustible area to combustible area (porosity). This paper described the experimental results of flame spread experiments along randomly arranged combustible cubes. Flame spread experiments conducted with changing porosity and size of experiment region. Porosity of flame spread probability set to 0 increased with the increase of experiment region. Subjected to finite size scaling in experimental results and examined the influence of number of grid on flame spread probability.
\end{abstract}

Key Words: Flame spread, Porosity, Percolation theory, Finite size scaling

\section{1. 緒言}

大規模地震発生後, 市街地では同時多発的に火災が発生 することがあり，火災の延焼により被害が拡大する. 火災 による二次被害を低減するには, 避難経路の確保が重要で あるが，火苂の延焼予測は困難である。そこで, 本研究で は市街地を可燃域が離散的に存在する系として, 市街地の 延焼がそれらの可燃域を火炎がつなぎ，拡がることで生じ る現象としてとらえ, 実験室規模の模擬実験から火災の延 焼を予測する手法の構築を目指す。実験結果の解釈にはス ケール比 $S(\equiv d / l$, 不燃間距離 $: d$, 火炎の予熱長さ $: l)$ を導入したパーコレーション理論を基礎としている(1)(2).

パーコレーション理論は, 空間上にランダムに分布する 点のつながりを確率的に表した理論である。また，パーコ レーション理論は無限に大きな領域を対象とするのに対し， 市街地火災の延焼および本実験は有限領域に限られる。こ のため, パーコレーション理論を延焼予測に応用する上で 有限領域の議論が必要となる。本報では，可燃性試料を用 いた燃え拡がり実験および思考実験から空隙率の変化に伴 う燃え拡がり確率の変化を調査した. これらの実験結果か ら, 実験領域の大きさが燃え拡がり確率に与える影響をパ ーコレーション理論を基に検討した. 実験領域の大きさと 燃え拡がりの関係に対してスケーリングを行うことで, 燃 え拡がりに与える領域のサイズ効果を明らかにした。

\section{2. 実験装置および方法}

図 1 に実験装置の概略を示す。可燃性試料として, 万紙 (ADVANTEC, No131, 厚さ $0.25 \mathrm{~mm}$ ) を一辺 $20 \mathrm{~mm}$ の立 方体に組み立てたものを使用した. Excel で発生させた乱数 により試料配置パターンを決定し, 不燃平板上に試料およ び空隙を配置した。試料への着火にはトーチにより行い, 燃え拡がりの様子を上部に設置したビデオカメラ（SONY,

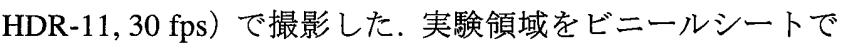
覆うことにより外乱の影響を防いだ.

実験領域は図 2 のように正方格子状とし, 格子間隔は $20 \mathrm{~mm}$ とした. 実験領域の大きさは $10 \times 10$ マスから最大で $100 \times 100$ までの範囲として実験を行った. 着火位置は実験 領域の角の試料とし, 領域の端から端まで火炎が燃え拡が った場合を燃え拡がり成功とする。これまでの研究で一辺 $20 \mathrm{~mm}$ の試料上の火炎は $20 \mathrm{~mm}$ の空陌を隔てて燃え拡がる ことができないことを確認している ${ }^{(3)}$. 図 2(b)の黒線は着 火後 10 秒毎の火炎の進行位置を示しており, 火炎の進行 は図 2(a)の破線（スリット）の位置で止まっていることか

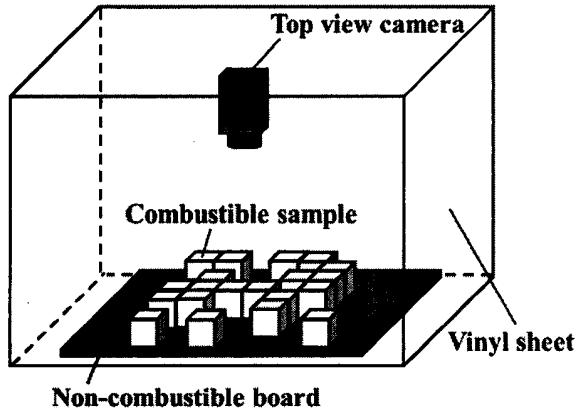

Fig.1 Schematic of experimental apparatus

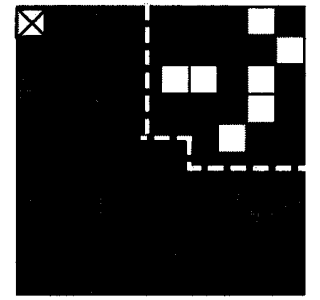

(a)

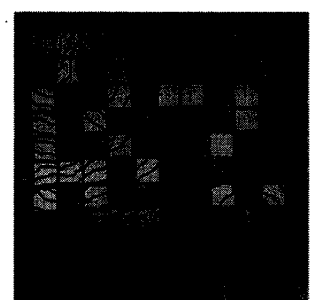

(b)

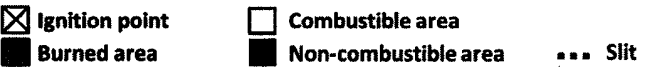

Fig.2 (a) Schematic of test sample placement,

(b) Flame spread trajectory of same sample placement

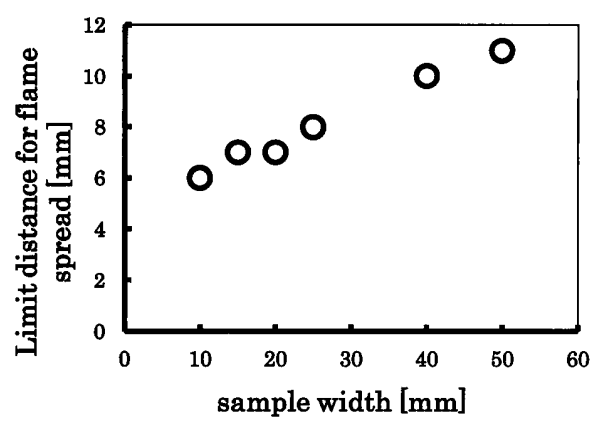

Fig.3 Relationship between limit distance for flame spread and sample width

ら, 試料の配置パターンからスリットの有無により, 燃え 拡がり範囲を予測することができる．著者らはこの然え拡 がり範囲の予測方法を思考実験として提案しており, 本研 究においても思考実験を用いた ${ }^{(4)}$. 思考実験は格子数ごと に空隙率を 40\% 80\%まで変化させて行い, 試料配置パタ 
ーンは 50 とした. 燃え拡がり成功回数をパターン数の 50 で除することで然え拡がり確率を求めた。図 3 は延焼限界 距離と試料幅の関係を示している。すなわち，試料幅（格 子幅）が小さくなることで $S<1$ となる条件が存在する. $S<1$ かつ $S \fallingdotseq 1$ のとき，図 4 に示す位置の試料に燃え拡がりが発 生すると仮定し, $S<1$ の思考実験も行った。

\section{3. 実験結果と考察}

\section{1 燃え拡がり確率}

図 $5(\mathrm{a})$ は $S>1,(\mathrm{~b})$ は $S<1$ の燃え拡がり確率と空隙率の関 係を示している. $S>1, S<1$ の場合ともに, 空隙率の増加に 伴い燃え拡がり確率は減少している。また，同じ空隙率で 比較した場合，S>1に比べ $S<1$ のほうが燃え拡がり確率は 高い值となる．また，燃え拡がり確率が 0 となる空隙率は 格子数によって異なっており，格子数が大きいほどより小 さな空隙率で然え搪がり確率が 0 となっている. 図 6 は燃 え拡がり確率が 0 となるときの空隙率と格子数の関係を示 している、燃え拡がり確率が 0 となる空隙率は格子数の増 加に伴い減少し，S>1の場合では $60 \%$ 付近に漸近し, $S<1$ の 場合では 70\%付近に漸近している。

\section{2 有限サイズスケーリング}

空隙率が増加することで，スリットが形成される確率が 高くなるため，燃え拡がり確率は低下する。また，S>1 に 比べ $\mathrm{S}<1$ のほうが然え拡がることのできる範囲が大きい ため，同じ空隙率でも高い燃え拡がり確率となる。

実験領域の大きさにより変化する燃え拡がり確率につい て，パーコレーション理論を基に検討する. 既存のパーコ レーション理論において，大きさ $L$ の系におけるつながり の有効閾值を $P(L)$ とすると，有限サイズスケーリングから， $P(L)$ とパーコレーション理論の閾值 $P_{c}$ との間に

$$
P(L)-P_{c} \propto L^{-1 / \nu}
$$

という比例関係が知られている(5).ここで， $\nu$ は臨界指数

(2 次元では 4/3) であり, 比例定数を $C$ とおくと

$$
P(L)=P_{c}+C L^{-0.75}
$$

と書き換えられる。空隙が領域全体につながることで然え 止まりとなることから，この関係が本実験にも適用できる と考え, $P(L)$ を格子数 $L \times L$ マスの然え拡がり確率が 0 とな るときの空隙率として実験結果を近似する， $C$ に適当な值 を用いて実験結果をフィッティングし, 然え拡がり確率が 0 となる閾值を決定した. 図 6 の近似曲線は $C=0.73$ とし たときであり, S>1 のときは $P_{c}$ を $59.3, S<1$ のときは $P_{c}$ を 71.0 としたとき, 実験結果におおよそ一致した。よって, 領域の大きさが然え拡がりに対して与える効果は $S>1$, $S<1$ でそれぞれ以下の式でスケールされる。

$$
\begin{aligned}
& P(L)=59.3+0.73 L^{-0.75}-(1) \\
& P(L)=71.0+0.73 L^{-0.75}-(2)
\end{aligned}
$$

これにより，有限領域の燃え拡がりに対する安全性を空隙 率により評価することができると考えられる。

\section{4. 結言}

実験領域の大きさを変化させた燃え拡がり実験から以下 の知見を得た。

1. いずれの領域サイズ, スケール比でも, 空隙率の増加に 伴い燃え拡がり確率は低下する。

2. 実験領域が大きくなるにつれ，燃え拡がり確率が 0 とな る空隙率は低下寸る。

3. 燃え拡がり確率が 0 となる空隙率と有限領域の大きさ の関係が $S>1$ に対して(1)式で, $S<1$ に対して(2)式で与えら れる。

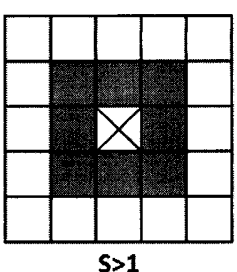

$\bigotimes$ Ignition point

Flame spread area

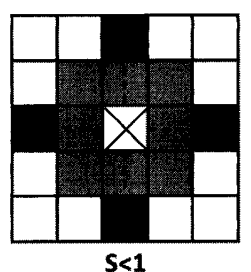

Flame jumping area
Fig.4 Position which can flame spread
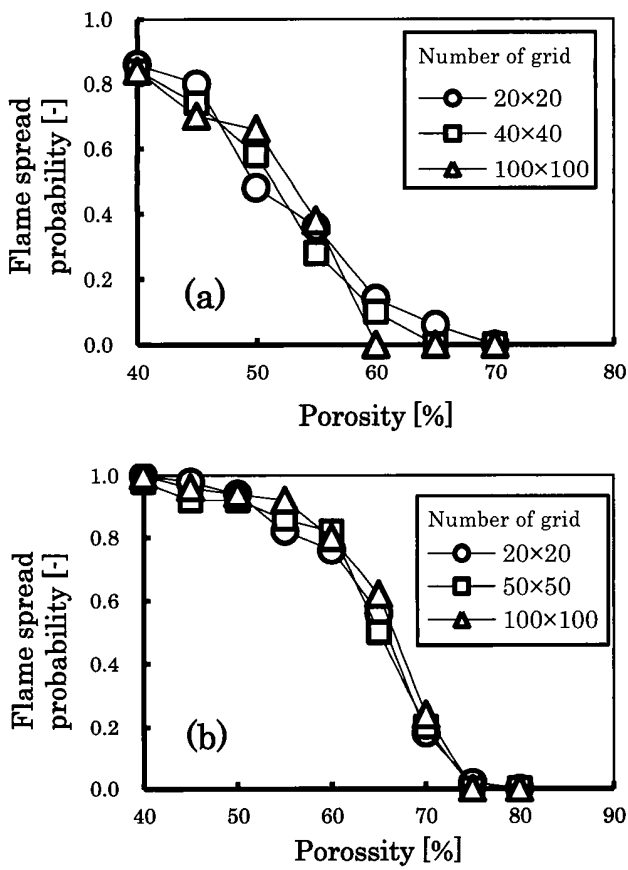

Fig.5 Relationship between flame spread probability and porosity; (a) $\mathrm{S}>1,(\mathrm{~b}) \mathrm{S}<1$

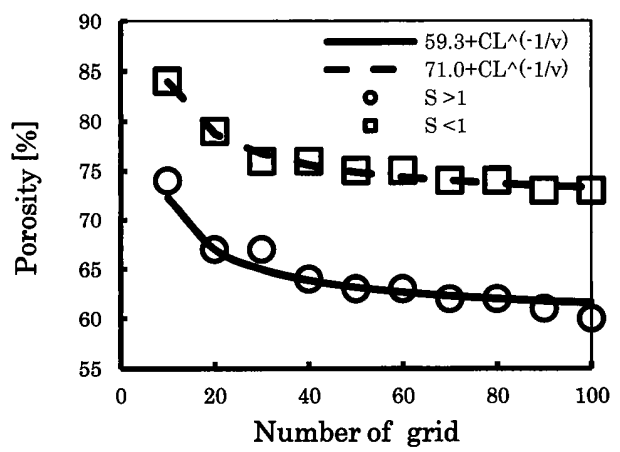

Fig.6 Relationship between porosity and number of lattice when flame spread probability set to 0

\section{参考文献}

(1)Abe. S, Ito. A, Torikai. H, Modern Applied Science, pp11-19 (2012).

(2)工藤，伊藤，鳥飼，日本燃焼学会誌, pp184-192 (2012).

(3)阿部, 伊藤, 鳥飼, 平成 24 年度日本火多学会研究発表会 概要集, pp86-87 (2012).

(4)阿部, 伊藤, 鳥飼, 日本機械学会熱工学コンファレンス 2012 講演論文集, pp319-320 (2012).

(5)D. Stauffer and A. Aharony，小田垣孝(訳)，パーコレー ションの基本原理 (2001). 